\title{
Erratum to: Macroprolactinemia, like hyperprolactinemia, may promote platelet activation
}

\author{
Inan Anaforoglu • Melek Eda Ertorer · Ilknur Kozanoglu • Birsel Unal • \\ Filiz Eksi Haydardedeoglu • Okan Bakiner · Emre Bozkirli • Neslihan Bascil Tutuncu • \\ Nilgun Guvener Demirag
}

Published online: 24 February 2010

(C) Springer Science+Business Media, LLC 2010

\section{Erratum to: Endocr}

\section{DOI 10.1007/s12020-009-9304-x}

In the original publication, the legends for Figures 1 and 2a-c were transposed, as was the information in the "Stimulated" and "Nonstimulated" columns in Table 2. The figures with their appropriate legends, as well as the corrected Table 2, are reprinted here.

The online version of the original article can be found under doi: 10.1007/s12020-009-9304-x.

I. Anaforoglu - M. E. Ertorer - F. E. Haydardedeoglu •

O. Bakiner · E. Bozkirli · N. B. Tutuncu - N. G. Demirag Division of Endocrinology and Metabolism, Department of Internal Medicine, Baskent University Faculty of Medicine, Ankara, Turkey

I. Kozanoglu

Department of Hematology, Baskent University Faculty of Medicine, Ankara, Turkey

B. Unal Department of Biochemistry, Baskent University Faculty of Medicine, Ankara, Turkey

N. G. Demirag ( $\square)$

Tıp Fakültesi İstanbul Hastanesi, Başkent Üniversitesi, Oymacı

Sokak No: 7, Altunizade, 34662 Istanbul, Turkey

e-mail: nilgunguvener@yahoo.com 


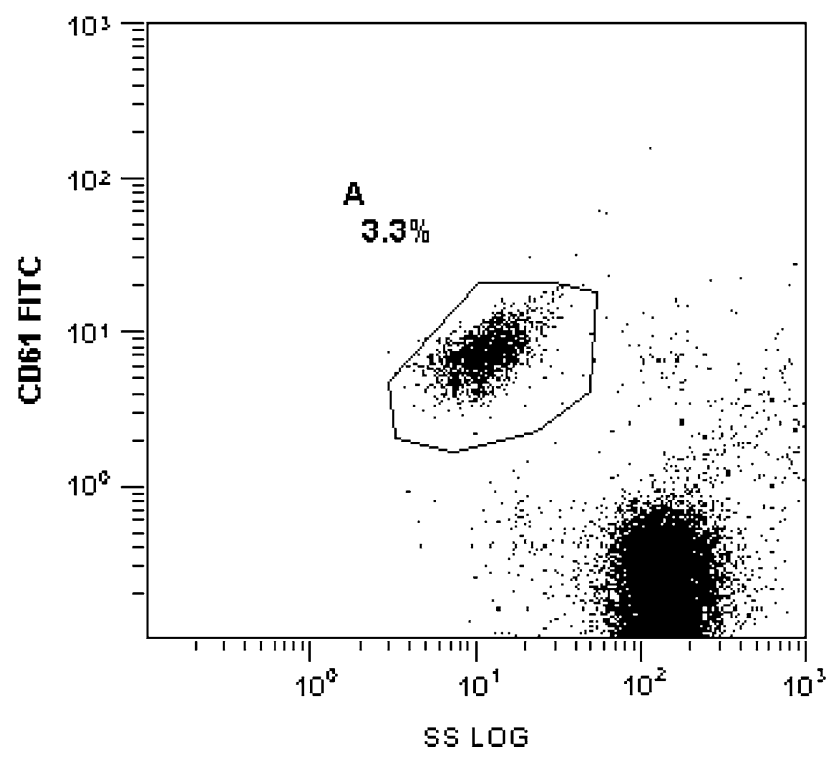

Fig. 1 Typical flow-cytometric plots for platelet activation (P-selectin expression), showing side scatter and positive labeling with the platelet-specific identifier (anti-CD61 antibodies)
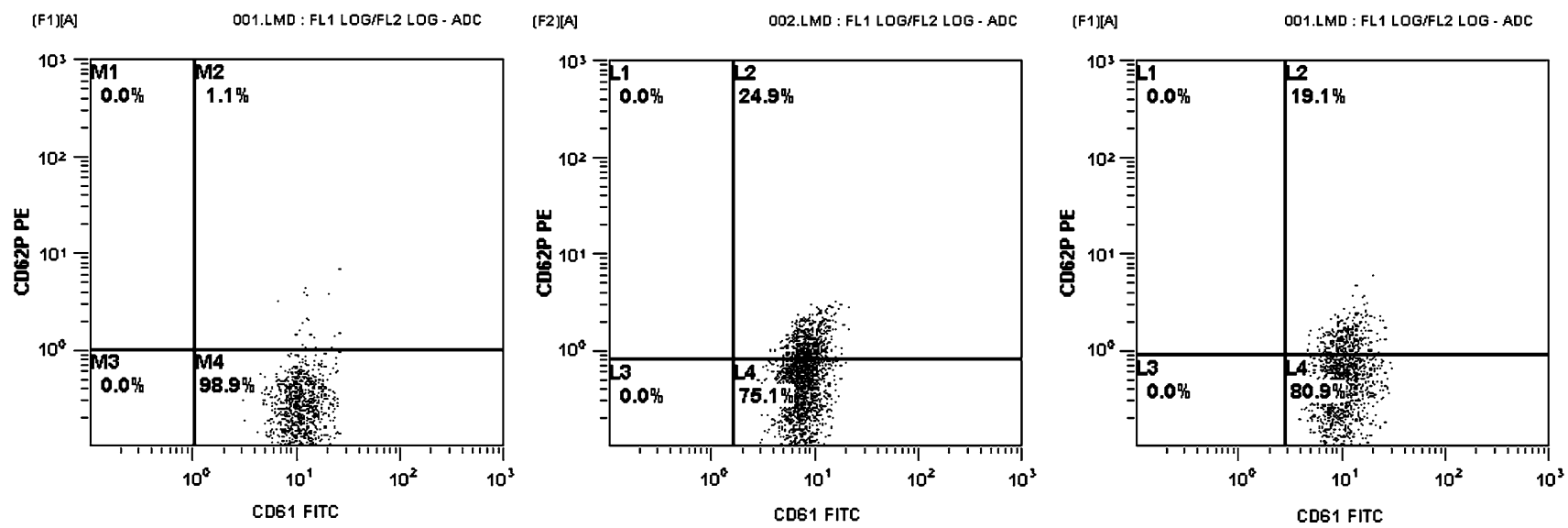

Fig. 2 Flow-cytometric plots of platelet activation, as measured by monoclonal anti-CD62P antibodies, in a normoprolactinemic subject (a), a patient with monomeric hyperprolactinemia (b), and a macroprolactinemic patient (c). ADP-stimulated expression was greater in both monomeric hyperprolactinemic patients and those

with macroprolactinemia compared with controls $(P=0.005$ and $P=0.003$, respectively), but expression did not differ significantly between the hyperprolactinemic and macroprolactinemic subgroups $(P=0.90)$

Table 2 P-selectin expression

\begin{tabular}{|c|c|c|c|c|c|c|}
\hline & \multicolumn{2}{|c|}{ Macroprolactin $(-)(n=20)$} & \multicolumn{2}{|c|}{ Macroprolactin $(+)(n=14)$} & \multicolumn{2}{|l|}{ Control $(n=44)$} \\
\hline & Non-stimulated (\%) & ADP-stimulated (\%) & Non-stimulated (\%) & ADP-stimulated (\%) & Non-stimulated (\%) & ADP-stimulated (\%) \\
\hline Minimum & 0.4 & 1 & 0.3 & 3.7 & 0.5 & 1 \\
\hline Maximum & 6.6 & 76.2 & 2.8 & 54.7 & 3.5 & 23.2 \\
\hline Median & 1.3 & 13.6 & 1.3 & 15.3 & 1.6 & 6.7 \\
\hline
\end{tabular}

